\title{
Juvenile nursery colonization patterns for the European flounder (Platichthys flesus): A latitudinal approach ${ }^{\text {¿ }}$
}

\author{
Filipe Martinho ${ }^{\text {a,* }}$, Henk W. van der Veer ${ }^{\text {b }}$, Henrique N. Cabral ${ }^{c}$, Miguel A. Pardal ${ }^{\text {a }}$ \\ a Centre for Functional Ecology (CFE), Department of Life Sciences, University of Coimbra, Apartado 3046, 3001-401 Coimbra, Portugal \\ ${ }^{b}$ Royal Netherlands Institute for Sea Research (NIOZ), PO Box 59, 1790 AB Den Burg Texel, The Netherlands \\ c Centro de Oceanografia, Faculdade de Ciências da Universidade de Lisboa, Campo Grande, 1749-016 Lisboa, Portugal
}

\section{A R T I C L E I N F O}

\section{Article history:}

Received 17 January 2013

Received in revised form 4 July 2013

Accepted 15 July 2013

Available online 23 July 2013

\section{Keywords:}

Latitudinal variations

Spawning

Metamorphosis

Otolith microstructure analysis

European flounder

Countergradient growth compensation

\begin{abstract}
A B S T R A C T
In this work, we analysed the latitudinal trends in the nursery habitat colonization processes of the European flounder (Platichthys flesus). This was accomplished by estimating the duration of the pelagic and metamorphic stages, as well as the duration of the spawning period, in several nursery areas across its geographical distribution range in the European Atlantic Coast: Mondego estuary (Portugal), Vilaine estuary (France), Slack estuary (France), Wadden Sea (Netherlands) and the Sørfjord (Norway). All juvenile flounders were captured with beam trawls in June/July 2010, and otolith microstructure was used to determine the duration of each stage by means of daily growth increments. The pelagic and metamorphic stages were longer at the middle of the distribution range, and lasted in total up to two months after hatching. The spawning period occurred between midJanuary and early-July over the species' distribution range, with a time lapse of nearly two months between the Mondego estuary and the Sørfjord, as a consequence of warmer water temperature earlier in the season in southern areas. In general, total length of the captured fish showed a latitudinal cline between the northernmost and southernmost sampling sites, with higher values at the middle of the distribution range. The results also suggested the existence of a countergradient growth compensation mechanism in the northernmost populations. Apart from temperature, which sets the general metabolic pace of organisms, differences between sites were also related with local features, such as the extension of the continental platform and adaptations to transport and retention mechanisms.
\end{abstract}

C 2013 Elsevier B.V. All rights reserved.

\section{Introduction}

Estuarine and shallow coastal habitats provide important nursery grounds for many flatfishes worldwide (e.g. Grioche et al., 1997; Martinho et al., 2009, 2010; van der Veer et al., 1991, 2011). For most of the marine fish that use these areas as nursery grounds, spawning takes place offshore, implying the migration of pelagic larvae or recently metamorphosed benthic juveniles from the continental shelf into estuarine and coastal areas (Grioche et al., 1997; Koutsikopoulos and Lacroix, 1992). Larval dispersion across the continental shelf has several advantages, including the colonization of new settlement habitats and minimization of intraspecific competition (Bailey et al., 2005). However, an increasing duration of the pelagic stage might also lead to a longer exposure to unfavourable hydrodynamic conditions and predation, resulting in higher mortality rates (Duffy-Anderson et al., 2011; Hovenkamp and Witte, 1991). This is particularly important for flatfishes, since they

\footnotetext{
is Given his role as Guest Editor, H.W. van der Veer had no involvement in the peerreview of this article and has no access to information regarding its peer-review. Full responsibility for the editorial process for this article was delegated to A.D. Rijnsdorp.

* Corresponding author. Tel.: + 351239855 760; fax: + 351239855789.

E-mail address: fmdm@ci.uc.pt (F. Martinho).
}

represent an extreme in the process of metamorphosis between larvae and juveniles (Bailey et al., 2008; Geffen et al., 2007).

For flatfishes, recruitment strength is determined mainly during the pelagic stage (Bolle et al., 2009; van der Veer, 1986; van der Veer et al., 2000), being later regulated on post-settlement stages (e.g. Ustups et al., 2013; van der Veer, 1986). Nevertheless, some studies have suggested that the factors controlling recruitment of a species vary over its geographic range, along a latitudinal gradient (e.g. Miller et al., 1991; Pauly, 1994; van der Veer et al., 2000; van der Veer and Leggett, 2005; Vinagre et al., 2008). Hence, it becomes of interest to adopt a macroecological approach to examine fish-environment relationships, since the latitudinal position is a good descriptor of the adaptation of populations to the local environment and of their tolerance to climate fluctuations (Brunel and Boucher, 2006; Hermant et al., 2009).

Latitude is a proxy for several environmental gradients such as temperature, seasonality and insolation, which are cross-correlated and interact among them (Willig et al., 2003). In particular, temperaturemediated processes control a major part of a fish's life cycle (Fonds, 1979; Pauly, 1994), setting the fundamental rates of metabolism, energy uptake, storage and use (Kooijman, 1993; Neill et al., 1994), including also spawning, growth and reproduction migrations (Buckley, 1982; Fincham et al., 2013; Neuheimer et al., 2011; Sims et al., 2004; Vinagre 
et al., 2008). Hence, it is expected that the influence of latitude in the early stages of flatfish is mainly felt through differential environmental conditions related to their position along the geographical distribution range.

In the Eastern Atlantic, the European flounder (Platichthys flesus, Linnaeus, 1758) is a common species, occurring in the coastal, brackish and fresh waters of Western Europe and from the White Sea to the Mediterranean and the Black Sea, ranging between $40^{\circ} \mathrm{N}$ and $72^{\circ} \mathrm{N}$. Presently, and apart from a geographically isolated set of populations in the Mediterranean and Adriatic Seas (Borsa et al., 1997), the current southern distribution limit of this species is assumed to be on the Portuguese coast (Cabral et al., 2007). The life cycle of flounder includes batch spawning in coastal areas, and the migration of young metamorphosing fish to nursery grounds, where benthic settlement concludes the pelagic larval stage (Nissling and Dahlman, 2010; van der Veer et al., 1991). In the particular case of flounder, the settling of larvae is considered to occur simultaneously with metamorphosis (ICES, 2008). This process is preceded by a combination of passive shoreward transport (Grioche et al., 1997) and active swimming adjusted to tidal rhythms (Jager, 1999), resulting in a more effective inshore transport of fish larvae into nursery areas (Grioche et al., 1997; Rijnsdorp et al., 1985).

Based on the work by Miller et al. (1991), who suggested that the patterns of recruitment variability occur over a latitudinal scale, the main objective of this work was to determine the existence of a latitudinal trend in the nursery colonization processes and in the spawning period of $P$. flesus across the northeastern Atlantic, where conspicuous gradients in environmental factors (mainly temperature) are anticipated. In particular, we estimated the duration of the spawning period, the pelagic and metamorphic stages, as well as the geographical differences in total length and length-weight relationships of juveniles, in order to determine whether latitude imposes a significant influence on the life cycle of flounder over its distribution range.

\section{Material and methods}

\subsection{Study sites and juvenile fish collection}

Flounder 0-group juveniles were collected in several estuarine and shallow coastal nurseries covering a range of $20^{\circ}$ in latitude: Sørfjord (Norway), western Dutch Wadden Sea (The Netherlands), Slack estuary (France), Vilaine estuary (France) and Mondego estuary (Portugal) (Fig. 1). The sampling sites were selected in order to cover most of the geographical distribution range of $P$. flesus in European waters. More information of the sampling areas is presented in Table 1.0-Group juvenile flounders were collected in the estuarine nurseries between midJune and mid-July 2010, using several beam trawl tows. The sampling dates were chosen based on the spawning period reported in literature, in order to ensure that spawning and larval migration towards the nursery grounds had finished. Since the aim of this study was not to analyse trends in juvenile densities, differences between sampling methods were not accounted for. All beam trawls were fitted with a $5 \mathrm{~mm}$ mesh size in the cod end, in order to ensure a similar selectivity for flounder juveniles. After collection, all fish were transported in iceboxes to the laboratory and frozen for later analysis.

Average monthly sea surface temperature (SST) data for 2010 in the coastal area was obtained from the International Comprehensive Oceanatmosphere Data Set (ICOADS) online database (http://dss.ucar.edu/

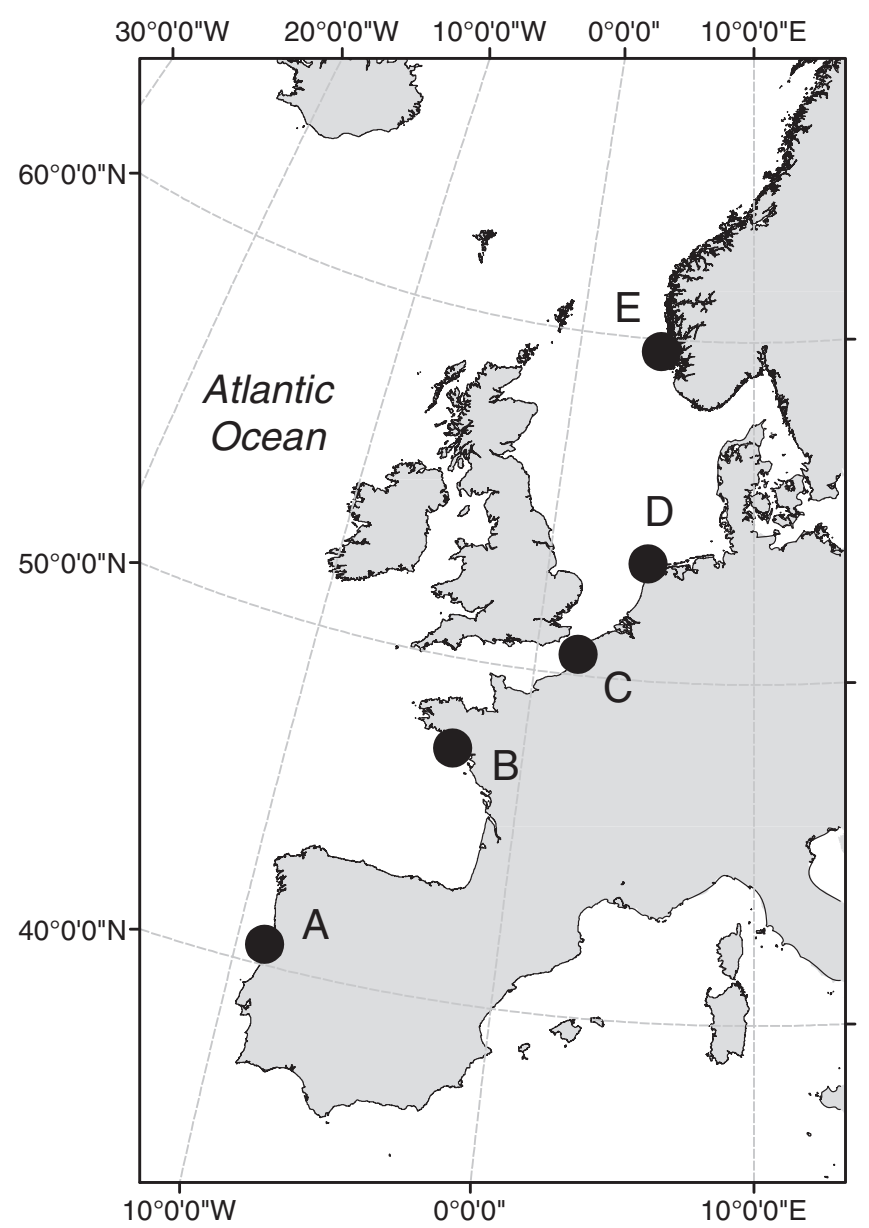

Fig. 1. Geographical location of the five sampled nursery areas of 0-group Platichthys flesus in the Eastern Atlantic: A - Mondego estuary, B - Vilaine estuary, C - Slack estuary, D - Dutch Wadden Sea, E - Sørfjord.

pub/coads, dataset 540.1, Worley et al., 2005), covering the $1^{\circ}$ Lat $\times 1^{\circ}$ Long square nearest to each nursery ground sampled.

\subsection{Data analysis}

All fish were measured (total length, TL, mm) and weighed (wet weight, $\mathrm{W}, \mathrm{g}$ ), and the respective length-weight relationships were determined for each population. In a sub-sample of randomly chosen juvenile fish from each location covering the whole range of total lengths observed, left sagittae otoliths were removed, cleaned and mounted with sulcus up on microscope slides (Sørfjord, $n=14$; Wadden Sea, $\mathrm{n}=14$; Slack Estuary, $\mathrm{n}=17$; Vilaine Estuary, $\mathrm{n}=$ 17; Mondego estuary, $\mathrm{n}=12$ ). Left otoliths were chosen due to their more symmetrical shape, when compared to the right one (ICES, 2008). Otoliths were polished in the sagittal plane using $0.1 \mu \mathrm{m}$ sandpaper until the daily rings in the nucleus were visible. All daily increment counts were made using a light microscope at $100 \times$ and $400 \times$ magnifications for the peripheral areas, and at $1000 \times$ magnification for

Table 1

Summary of the main features of each Platichthys flesus nursery area sampled in this study.

\begin{tabular}{|c|c|c|c|c|c|}
\hline Nursery area & Country & Latitude & Longitude & Area $\left(\mathrm{km}^{2}\right)$ & Sampling Date \\
\hline Sørfjord & Norway & $60^{\circ} 30^{\prime} \mathrm{N}$ & $5^{\circ} 24^{\prime} \mathrm{E}$ & 74.2 & 17.07.2010 \\
\hline Wadden Sea (Balgzand) & Netherlands & $53^{\circ} 04^{\prime} \mathrm{N}$ & $5^{\circ} 03^{\prime} \mathrm{E}$ & 52.0 & 17.07.2010 \\
\hline Slack Estuary & France & $50^{\circ} 48^{\prime} \mathrm{N}$ & $1^{\circ} 36^{\prime} \mathrm{E}$ & 0.01 & 01.07.2010 \\
\hline Vilaine Estuary & France & $47^{\circ} 30^{\prime} \mathrm{N}$ & $2^{\circ} 30^{\prime} \mathrm{W}$ & 11.3 & 02.07 .2010 \\
\hline Mondego Estuary & Portugal & $40^{\circ} 08^{\prime} \mathrm{N}$ & $8^{\circ} 52^{\prime} \mathrm{W}$ & 8.6 & 17.06.2010 \\
\hline
\end{tabular}


the nucleus. Otolith microstructure was used to determine the duration of the different stages: pelagic (larval), metamorphosis (time period between first morphological asymmetry and the completion of juvenile features) and benthic (post-metamorphosis juveniles), in agreement with Geffen et al. (2007) and Daverat et al. (2012). The pelagic stage corresponded to the otolith nucleus, the metamorphic stage corresponded to the rings between the innermost and the outermost accessory primordia. The duration of the benthic stage was determined as the number of rings between the first ring after the outermost accessory primordial (i.e. the first ring that forms a complete circle after the outermost accessory primordia) and the edge of the otolith. The total increment counts provided an estimate of the total age in days, in accordance with Bos (1999) and Amara et al. (2009). Otolith increments were counted twice, and the duration of each stage (days) was regarded as the average of the two counts. In case the difference between the two counts was more than $10 \%$, the otolith was removed from further analyses. In each otolith, the maximum diameter through the nucleus was measured under a microscope. Uncertainty in the identification of early increments was calculated by interpolation over the distance between the hatching ring and the first clearly defined increment, using an average otolith growth rate of $0.6 \mu \mathrm{m} \cdot \mathrm{d}^{-1}$ determined for plaice (Pleuronectes platessa) (Fox et al., 2007; Hovenkamp and Witte, 1991). However, and since this early growth rate has not been validated for flounder, these values were not included in the overall counts, but were considered as the underestimation of the pelagic stage.

Hatch dates were estimated from age (number of daily rings) and date of capture. The duration of the spawning period was estimated by the difference between hatch dates of the oldest and youngest specimens for each location. The duration of the spawning period was compared along the European Atlantic coast, based on the present work and other published literature.

\subsection{Statistical analysis}

Geographical differences in total length were assessed using a Kruskal-Wallis ANOVA, since data did not meet the necessary requirements for an ANOVA procedure, followed by Dunn's pairwise multiple comparison a posteriori tests, whenever the null hypothesis was rejected. Analysis of covariance (ANCOVA) was used to compare length-weight relationships amongst locations (using logtransformed data, in order to compare the slope of the regressions), as well as geographical differences in the slopes of the linear relationships between total length, otolith diameter and age (in days). Differences in the timing of spawning and both timing and duration of the pelagic and metamorphic stages were evaluated by means of ANOVA, followed by Tuckey's pairwise multiple comparison a posteriori tests, whenever the null hypothesis was rejected.

Age-standardized total length was obtained by fitting the regressions obtained for total length and age, and given the example of fish with 120 days, in order to allow for direct comparisons between sites. For each site, the respective confidence level of 0.95 was also determined. All statistical tests were performed in R software ( $\mathrm{R}$ Development Core Team, 2009), considering a significance level of 0.05 .

\section{Results}

Average SST values showed a typical variation of temperate ecosystems in the five nursery areas (Fig. 2). The highest thermal amplitude was observed in the northern areas near Sørfjord and the Dutch Wadden Sea, ranging between $3.5^{\circ} \mathrm{C}$ and $15.2{ }^{\circ} \mathrm{C}$, and between $3.9{ }^{\circ} \mathrm{C}$ and $17.4{ }^{\circ} \mathrm{C}$, respectively. Both milder winter conditions and higher summer temperatures were observed in the southern areas, with SST ranging from $6.0^{\circ} \mathrm{C}$ to $17.4{ }^{\circ} \mathrm{C}$ near the Slack estuary, from $8.7^{\circ} \mathrm{C}$ to $17.9^{\circ} \mathrm{C}$ near the Vilaine estuary, and between $13.3^{\circ} \mathrm{C}$ and $18.0{ }^{\circ} \mathrm{C}$ near the Mondego estuary.

Significant linear relationships between juvenile flounder total length and otolith diameter were obtained for all sampling sites (Fig. 3). In this case, the slope in the data from the Sørfjord was significantly different than those in the other sites, with fish having larger otoliths than those in southern populations ( $F=14.76 ; \mathrm{p}<0.05)$. Significant linear relationships were also obtained between total length and age (in days) for all sites (Fig. 4). However, no significant differences were observed between sites $(\mathrm{F}=0.36 ; \mathrm{p}>0.05)$.

A comparison of the duration of pelagic, metamorphic and benthic (until sampling occurred) stages between all study sites showed that the start of each stage occurred earlier at lower latitudes (Fig. 5). The underestimation of the early pelagic stage, based on plaice growth data (Fox et al., 2007; Hovenkamp and Witte, 1991), was determined to be 15.8 days ( $\mathrm{sd}=3.1$ ); still, this value was not included in the estimation of the subsequent stages. The pelagic stage was different between sites, particularly between the middle and the edge sampling areas $(F=21.80 ; \mathrm{p}<0.05)$. At the northern edge near Sørfjord, this stage lasted on average for 23.5 ( $s d=6.5$ ) days, while at the southern edge near the Mondego estuary this stage lasted for 29.6 ( sd = 3.2) days. In the centre of its geographical crange, the pelagic stage duration of $P$. flesus lasted for 34.5 ( $\mathrm{sd}=4.7$ ) days near the Wadden Sea, 23.0 ( $s d=3.3$ ) days near the Slack estuary and 33.6 ( $s d=3.9$ ) days near the Vilaine estuary. The metamorphic stage was also different between sites $(\mathrm{F}=10.39 ; \mathrm{p}<0.05)$, being shorter at

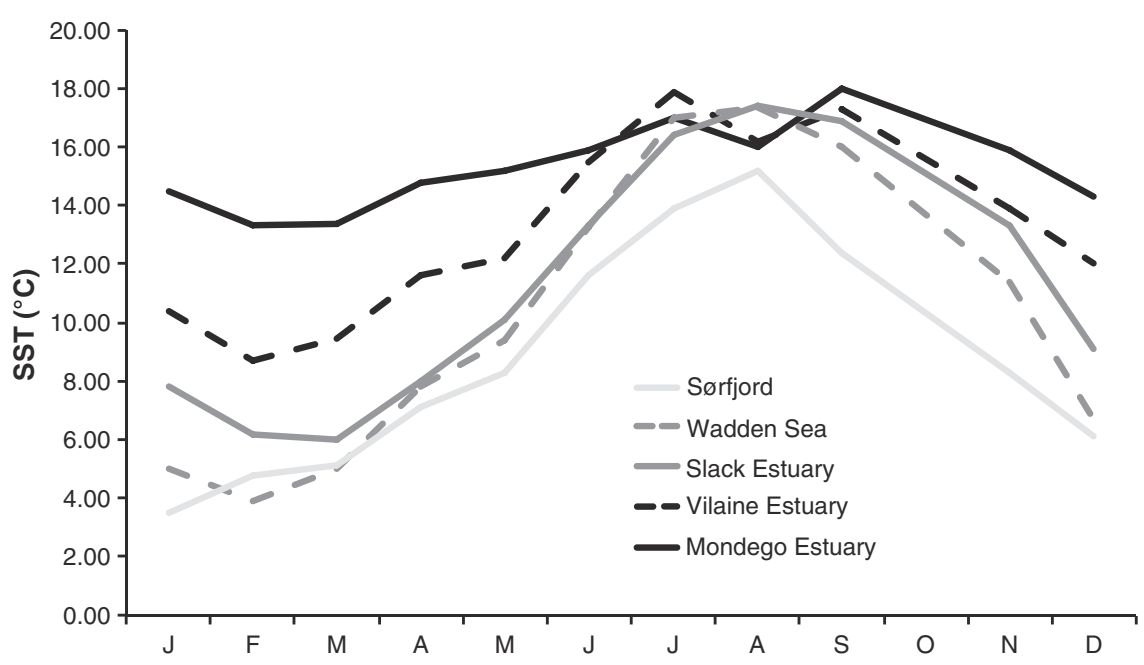

Fig. 2. Monthly sea surface temperature in 2010 for the $1^{\circ}$ Latitude $\times 1^{\circ}$ Longitude square nearest to each sampled nursery area. 

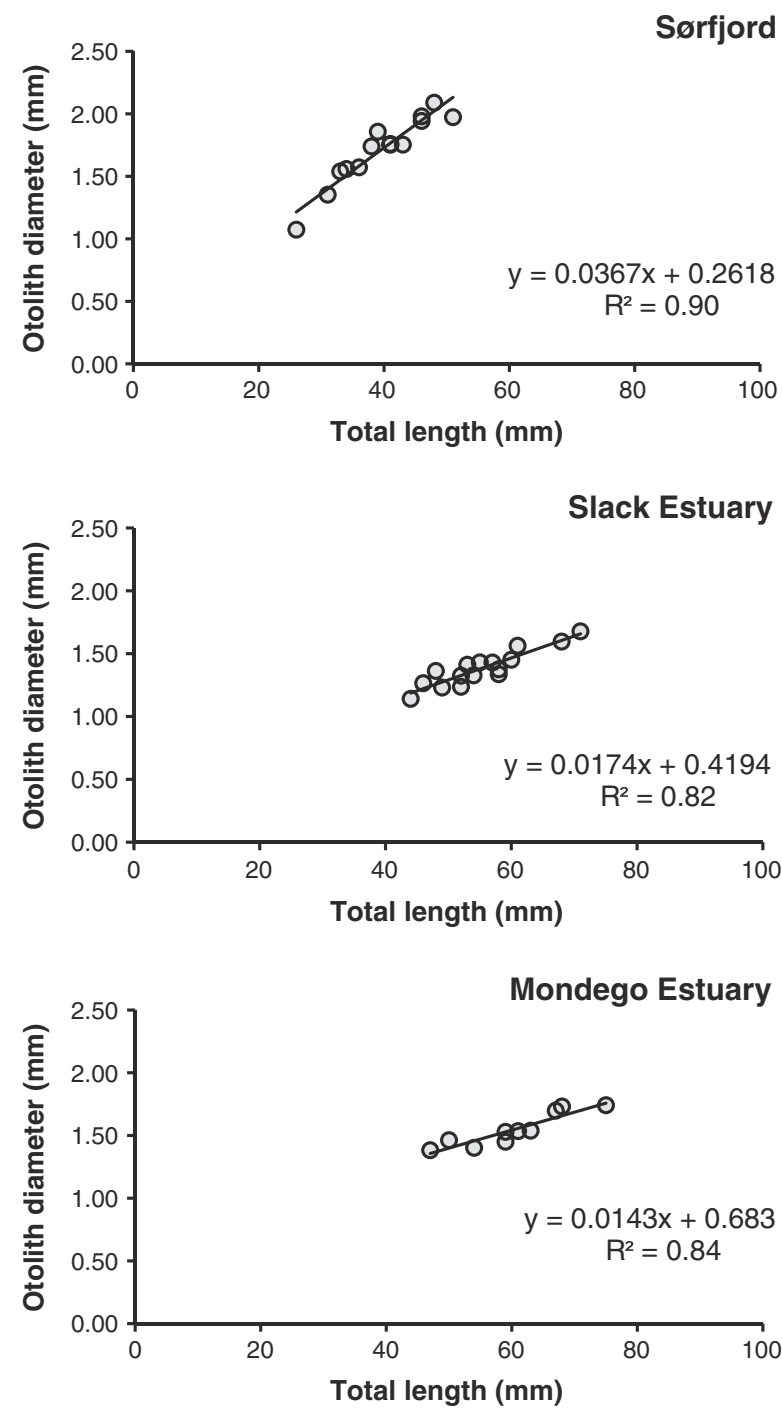

Wadden Sea
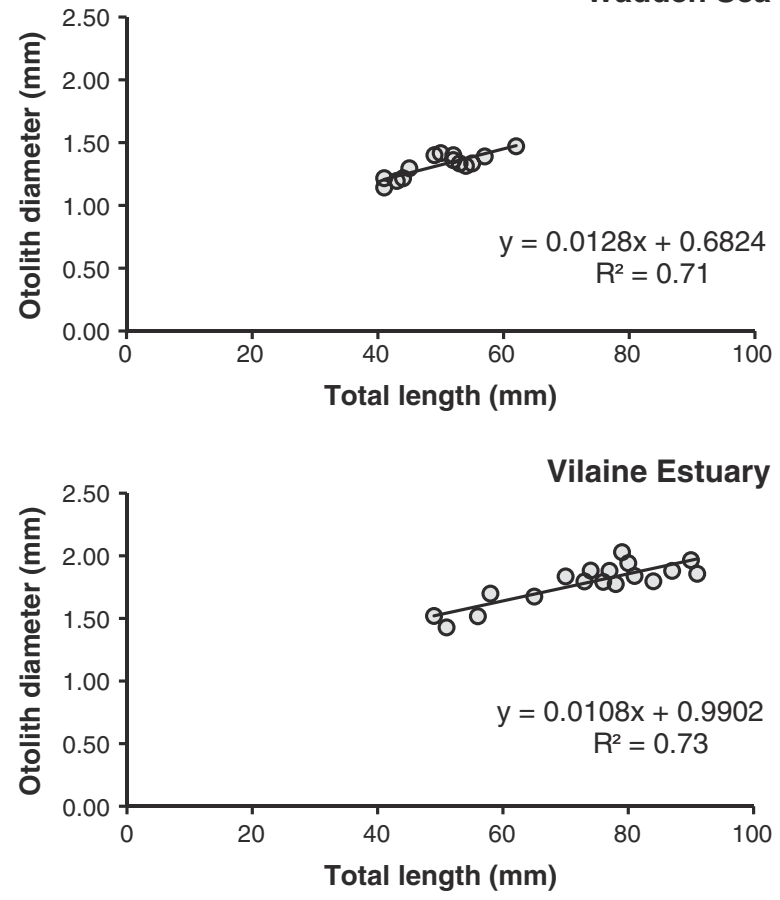

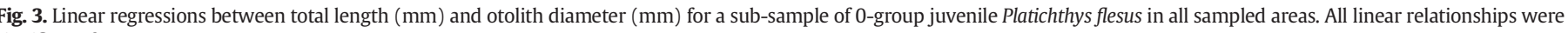
significant for $\mathrm{p}<0.05$.

the extremes of the species' distribution range: 14.1 ( $\mathrm{sd}=2.8$ ) days in Sørfjord and 15.0 ( sd = 2.7) days in the Mondego estuary, and longer in the centre: $16.5(\mathrm{sd}=1.2$ ) days in the Dutch Wadden Sea, 20.0 $(s d=2.5)$ days in the Slack estuary and $20.6(s d=5.7)$ days in the Vilaine estuary. Differences in the time of spawning, larval and metamorphosis were also found across sites $(\mathrm{F}=45.83, \mathrm{p}<0.05 ; \mathrm{F}=$ 48.41, $\mathrm{p}<005 ; \mathrm{F}=50.85, \mathrm{p}<0.05$, respectively).

The onset and duration of flounder's spawning period, based on the present and other published literature, showed a latitudinal cline with spawning starting earlier at lower latitudes (Fig. 6). The estimate of the spawning duration for the Vilaine area was nearly three months, while in the other areas spawning duration was less than one month. In particular, spawning near the Mondego estuary lasted from lateFebruary (27th February) to late-March (24th March); in the northern Bay of Biscay (Vilaine), spawning took place between mid-January (14th January) and mid-April (18th April), while in the northern French oast (Slack), spawning occurred from late-March (25th March) to mid-April (19th April). At higher latitudes, spawning lasted between early-April (9th April) and early-May (1st May) near the Dutch Wadden Sea (southern North Sea), and between late-April (25th April) and midMay (18th May) near the Sørfjord (northern North Sea).

Larger fish were captured in the Vilaine estuary (France) (TL, $74.3 \mathrm{~mm}$ (sd = 12.4), $\mathrm{n}=54$ ), and in the Mondego estuary ( $\mathrm{TL}, 60.3 \mathrm{~mm}$ ( $\mathrm{sd}=8.5), \mathrm{n}=12$ ) (Fig. 7A). The smaller fish were found in the northernmost areas: Sørfjord (TL, $39.5 \mathrm{~mm}$ ( $\mathrm{sd}=7.1$ ), $\mathrm{n}=70$ ), Wadden Sea (TL, $51.5 \mathrm{~mm}$ ( $\mathrm{sd}=4.8), \mathrm{n}=42$ ) and Slack estuary (TL, $54.9 \mathrm{~mm}$ ( $\mathrm{sd}=6.8), \mathrm{n}=84$ ). Significant differences in total length were observed between the juvenile flounders from the Vilaine and the northernmost nurseries (Sørfjord, Dutch Wadden Sea and Slack estuary), between fish from the Mondego estuary and Sørfjord, between the Slack Estuary and Sørfjord, and between the Dutch Wadden Sea and Sørfjord $(\mathrm{H}=53.93 ; \mathrm{p}<0.05)$.

Age-standardized total length for a fish of 120 days old, confirmed the previous trend (Fig. 7B), with similar total length observed for the two northern populations (Sørfjord and Dutch Wadden Sea), lower values in the southernmost area (Mondego estuary) and larger fish in the two French estuaries. Length/weight relationships were similar among sites, with the exception of the Mondego estuary ( $F=794.60$; $\mathrm{p}<0.05$ ) (Fig. 8).

\section{Discussion}

\subsection{Pelagic, metamorphic and benthic stages}

The early population dynamics of fish are mainly controlled by density-independent mechanisms, acting on the early life stages (eggs and larvae), prior to the nursery residency stage (Leggett and Frank, 1997; van der Veer, 1986; van der Veer and Leggett, 2005; van der 

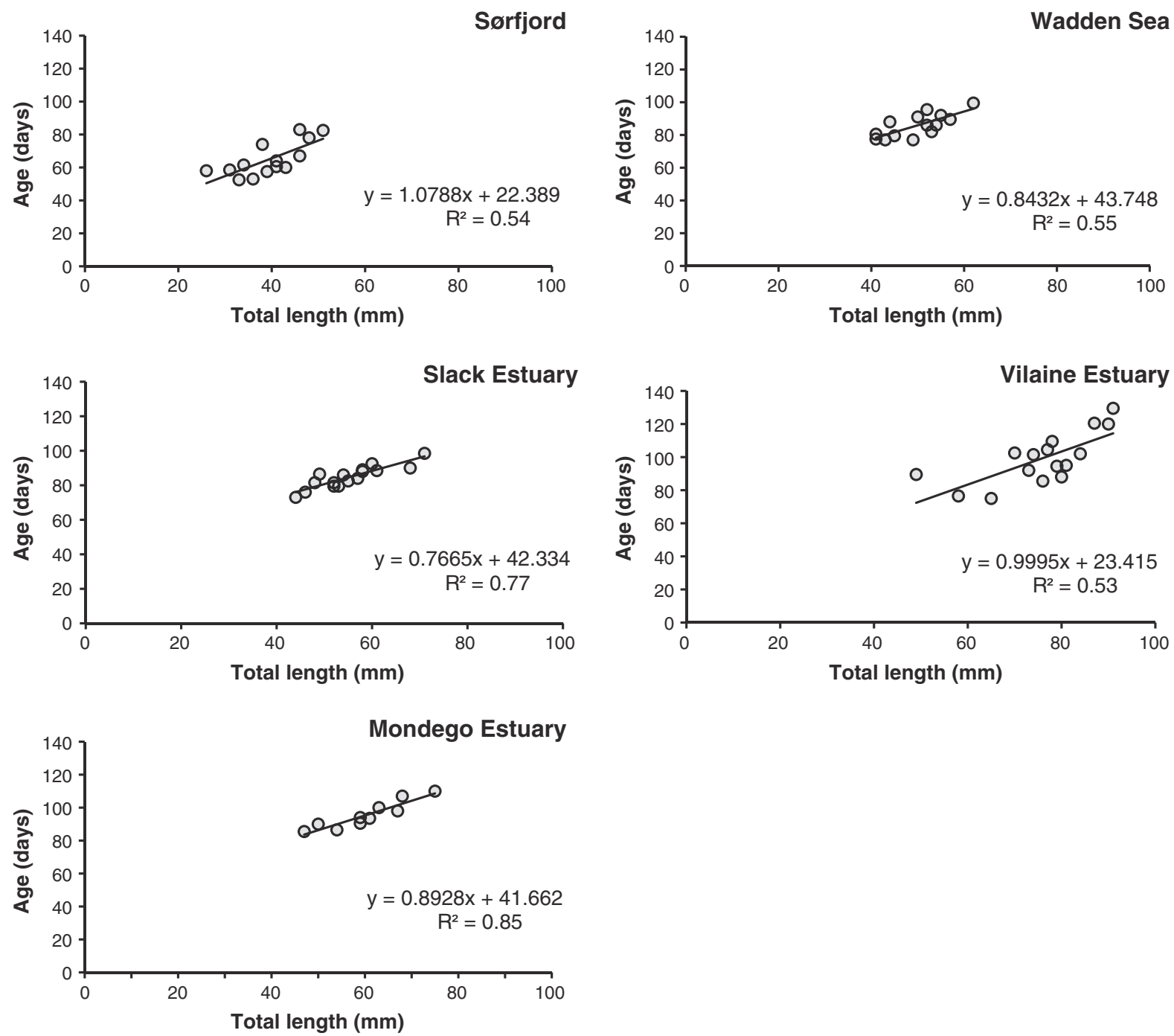

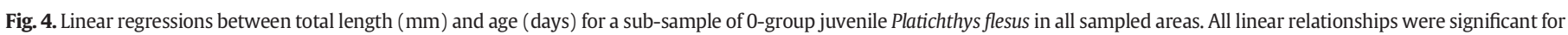
$\mathrm{p}<0.05$.

Veer et al., 2000). In this sense, adopting a large-scale ecological point of view allows for the establishment of trends along a species distribution range, relating the duration of the early-life stages to the prevalent environmental conditions. In response to the different temperature regimes (Heath, 1992), the onset of spawning and consequently the start of the pelagic, settlement and benthic stages exhibited a delay between the southernmost $\left(40^{\circ} \mathrm{N}\right)$ and the northern area $\left(60^{\circ} \mathrm{N}\right)$ of nearly two months, similar to other flatfishes such as the common sole (Vinagre et al., 2008) and winter flounder Pseudopleuronectes americanus (Sogard et al., 2001).

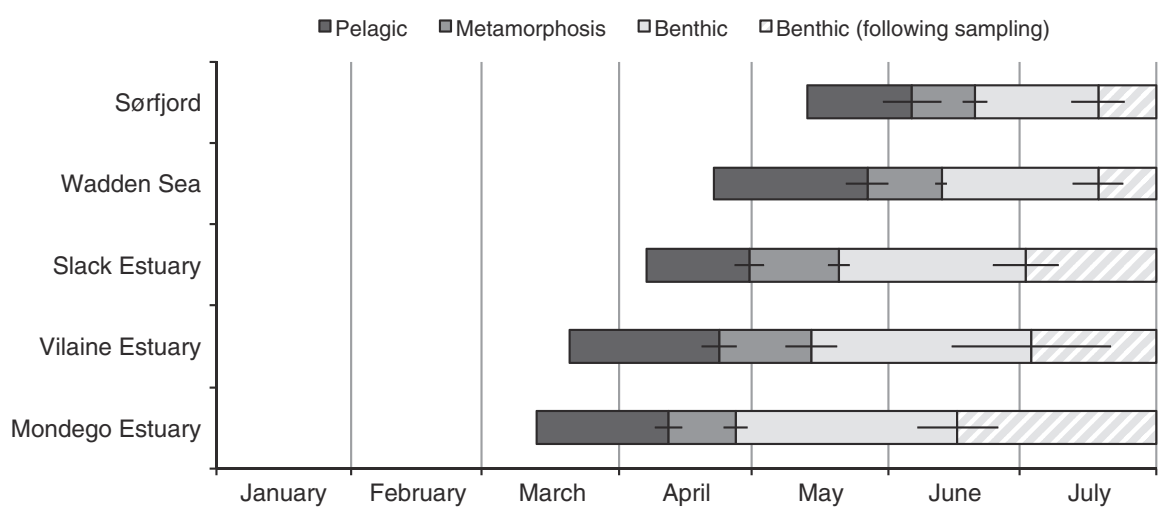

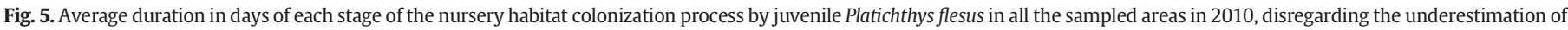

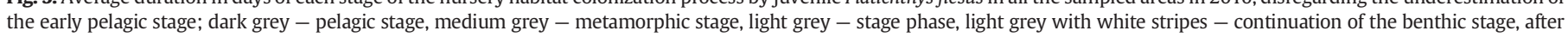
sampling was performed. Horizontal bars represent standard deviation. 


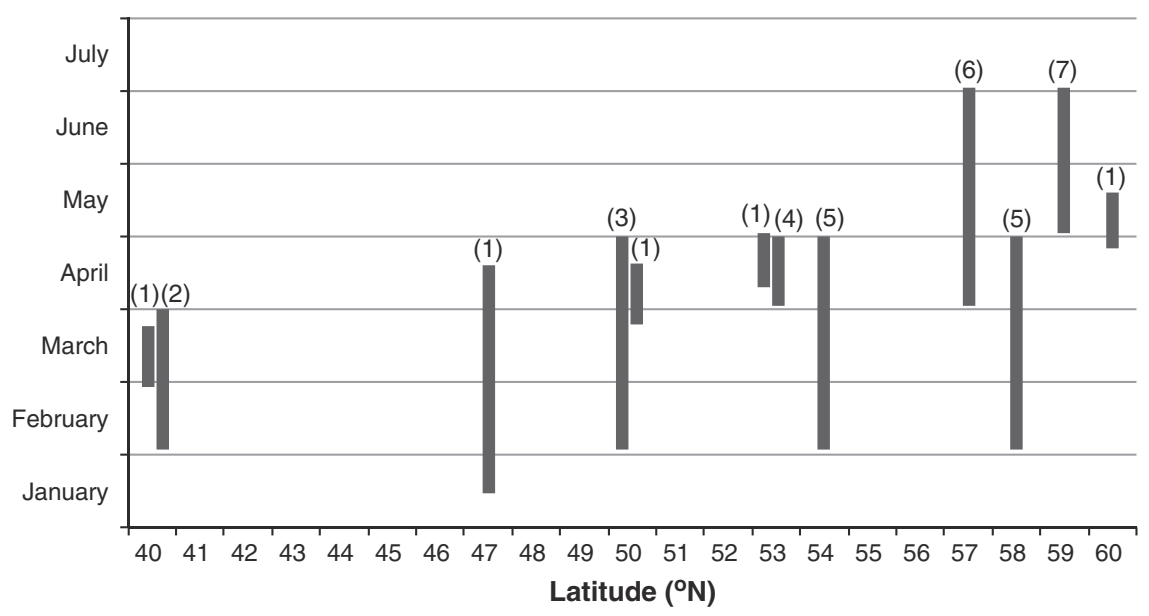

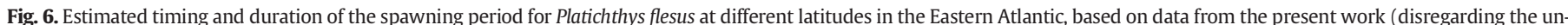

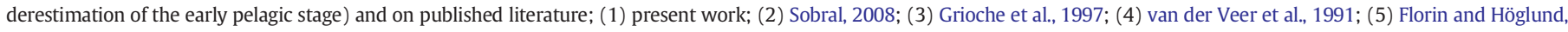
2008; (6) Molander, 1964; (7) Curry-Lindahl, 1985.

In general, the pelagic stage lasted longer at the southern limit and in the centre of the distribution range, varying between an average of 30 days in the Portuguese coast and 34 in the French coasts and Dutch Wadden Sea. In the northernmost areas, the pelagic stage lasted on average 24 days. These results contrast with the findings by Minami and Tanaka (1992), who determined a positive relationship between the duration of egg and larval stages and latitude for several flatfishes. In fact, the duration of the egg and larval stages in plaice (P. platessa) has been determined to be temperature-dependent, since higher water temperature reduces the development time (Hyder and Nash, 1998). The duration of the pelagic stage of about one month confirmed previous results for the North Sea (e.g. Kerstan, 1991; van der Veer et al.,

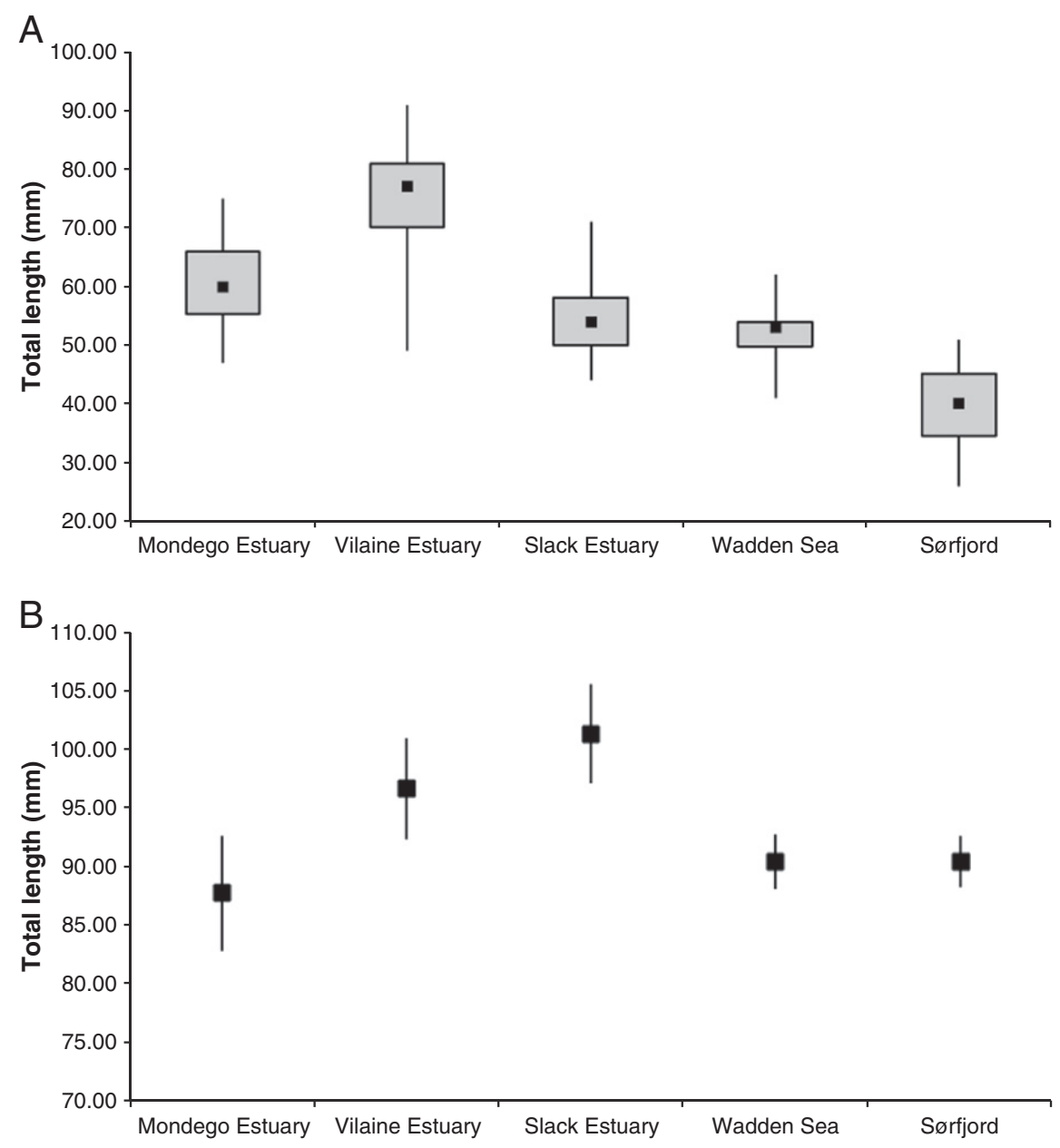

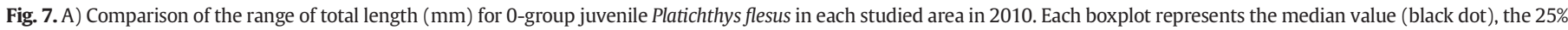

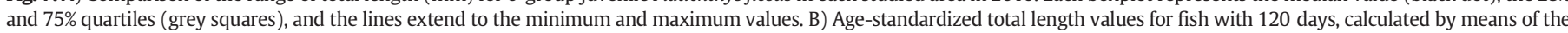
significant linear relationships obtained in all sampling sites between total length $(\mathrm{mm})$ and age (days). Error bars represent the 0.95 confidence level. 

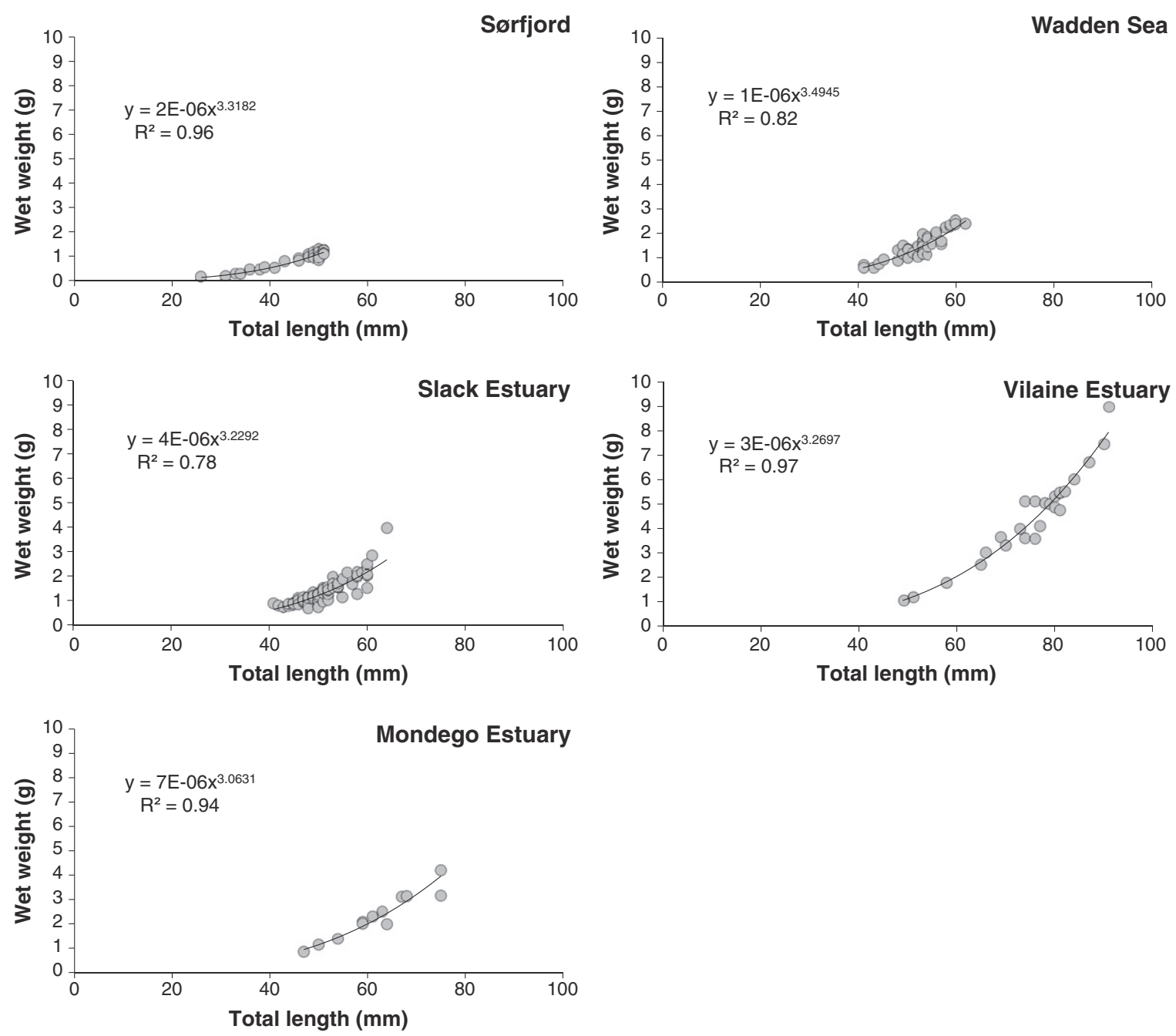

Fig. 8. Length/weight relationships for the juvenile Platichthys flesus in the selected nursery grounds.

1991). However, given the level of uncertainty identified for the early pelagic stage (ca. 16 days), the whole duration of this stage may be up to 50 days.

The differences in the duration of the pelagic stage might also be related to the distance between the spawning grounds and the nursery habitats (Bailey et al., 2008). In the Eastern Atlantic, flounder spawning grounds are located over the continental shelf, between 20 and $50 \mathrm{~m}$ depth in the English Channel, southern Bight of the North Sea and Baltic (Dando, 2011; Grioche et al., 1997; Sims et al., 2004; van der Veer et al., 1991). Despite being relatively close to the shore, the various spawning grounds are probably subjected to different environmental features, which include local topography, transport and retention mechanisms, leading to a differential delivery time of larvae towards estuarine nursery habitats, as reviewed in Bailey et al. (2005). In addition, the timing of spawning is likely adapted to the timing of prey biological cycles, seasonal and geographic abundance of predators, and seasonal changes in transport conditions (Bailey et al., 2005; Grioche et al., 1997).

As a transition stage between the pelagic and benthic realms, metamorphosis is a critical period in flatfish, affecting the feeding, growth, survival of the larvae (Yamashita et al., 2001) with consequences for the population dynamics (Leggett and DeBlois, 1994; van der Veer et al., 2000). The metamorphic stage, which co-occurs with benthic settlement (ICES, 2008), was shorter at the extremes of the surveyed distribution range. Depending on the relative location of spawning and nursery habitats, adaptations to local features might drive these differences, implying that the time frame for metamorphosis might not be equal across a species distribution range. Such adaptations include the use of retention mechanisms to remain within favourable areas, or conversely, taking advantage of transport pathways to adequate habitats, by means of Ekman transport or selective tidal stream transport (STST) (Bailey et al., 2005; Grioche et al., 1997; Rijnsdorp et al., 1985). However, these patterns might vary across geographical areas, as demonstrated for plaice (Bailey et al., 2005; Bergman et al., 1989; Rijnsdorp et al., 1985).

Metamorphosis in fish, and particularly in flounder, has been determined to be a temperature-dependent process (e.g. Hutchinson and Hawkins, 2004). The present results for the southern area of distribution corroborate this assumption, since the duration of this stage was shorter at lower latitudes characterised by warmer water temperature in the winter. However, this trend does not seem to apply to our results from the northernmost area, where the metamorphic stage was also shorter than in the central area of distribution. This may be attributed to the shorter duration of the growing season at the northernmost areas, where countergradient growth compensation might be occurring (Campos et al., 2009). Despite being exposed to lower temperatures at higher latitudes, fish benefit from higher productivity and a prolonged photoperiod during the growing season (Geffen et al., 2007), a particularly important aspect for a visual predator such as flounder (De Groot, 1971), enabling a faster growth. In addition, larval size at metamorphosis, coupled with the ability to feed and/or to tolerate food deprivation, is a crucial factor in determining the fishes' responses to environmental drivers for settlement (Geffen et al., 2007).

The timing of settlement relies on each species' spawning period, the spawning ground location and the duration of the pelagic stage 
(Martinho et al., 2008). In parallel with the previous stages, the onset of the post-metamorphic benthic stage occurred with a delay of nearly two months between the two furthest apart areas. Along the French coast, this stage occurred nearly simultaneously at both the Vilaine and Slack estuaries, mainly due to a more reduced pelagic stage of the Slack populations.

Taking into account the observed delay of each life stage with increasing latitude, the onset of each stage occurred at warmer water temperatures particularly in the southern areas, suggesting the adaptation of populations to local features, owing to possible genetic differences among them (Conover and Present, 1990).

\subsection{Latitudinal trends in the spawning season}

The present results, combined with data in published literature, confirm the existence of a latitudinal cline in the spawning season, in which spawning starts earlier at lower latitudes. As observed by Amara et al. (2000), warmer water temperature during the winter influences the beginning of the spawning season, which is in agreement with the present data. Besides temperature, latitudinal trends in photoperiod can also be an important factor for triggering spawning in flounder, as observed for the European seabass (Dicentrarchus labrax) and common sole Solea solea (Vinagre et al., 2008, 2009).

The spawning duration was longer in the centre of the distribution range, taking into account also data from literature. A novel aspect was that, unlike in other studies, spawning at higher latitudes near $60^{\circ} \mathrm{N}$ started earlier in the season. Since spawning is highly dependent on temperature (e.g. Fonds, 1979; Sims et al., 2004), it could be possible that in the recent years the onset of the spawning season might have occurred earlier, given the warming of seawater that has been observed over the Atlantic Ocean (see Hermant et al., 2009). As for the central area, the present results confirm the observations of Grioche et al. (1997), who showed that the spawning season off the French coast of the English Channel occurred between February and April. The exceptionally long spawning season of the Vilaine populations might also be explained by a wider origin than the populations settling in the other nurseries. In addition, recent work has provided an indication that phenotypic traits such as peak spawning are indeed affected by temperature and vary between populations (Fincham et al., 2013), as observed in this study.

\subsection{Variations in body size across the distribution range}

The relationship between total length of juvenile flounder and otolith diameter was similar in all sites, with the exception of the Sørfjord, where the slope of the regression was much steeper. As observed for the North Sea plaice (P. platessa), otolith growth might not only be a function of somatic growth, but can also be influenced by factors such as food availability, temperature and metabolic rates (Hovenkamp, 1990).

Results from the present work indicate that the pattern in total length of 0-group fish showed a latitudinal cline. The largest individuals were observed in the Vilaine estuary (France), followed by the Mondego estuary (Portugal), and the smallest fish were observed in the northern areas. In the southern areas, warmer water temperatures and an earlier start of the spawning season contribute to a faster growth and an earlier colonization of nursery grounds (Amara et al., 2000), as observed for other flatfishes such as the common sole (Vinagre et al., 2008). The fact that the northernmost fish exhibited a similar total length to those from lower latitudes suggests the occurrence of countergradient growth compensation. Accordingly, the northernmost populations seem to compensate for lower environmental temperatures by growing faster in the most favourable period. In fact, the phenotypic plasticity of growth with respect to temperature increases with latitude (Conover and Present, 1990), with fish showing a higher capacity for growth at higher latitudes (Campos et al., 2009; Conover and Present, 1990). In addition, juvenile flounders at the southern limit of their distribution range must be facing a high degree of physiological stress due to higher water temperatures (Pörtner et al., 2001).

In part, the present results seem to agree with the species range hypothesis proposed by Miller et al. (1991), in which populations at the edges of their distribution range should be more controlled by abiotic factors. This happens mainly since the boundary populations are living at the edge of their optimal thermal niche, with population dynamics being also controlled by local conditions, particularly hydrodynamics, that may overrule general latitudinal trends as suggested by Leggett and Frank (1997), van der Veer et al. (2000), van der Veer and Leggett (2005) and Freitas et al. (2008). Overall, temperature seems to exert a two-way response pattern on this species: on one hand, higher temperatures at the southern limit allow for an earlier start of the spawning season, while on the other hand it may limit growth (Vasconcelos et al., 2009), since flounder is typically a cold water species. In addition, local features must also contribute for a reduced fitness of these populations. These local features in the southern areas include the highly dynamic coastal zones, whose strong exposure to northerly winds and frequent upwelling events during the estuarine colonization induces offshore Ekman advection (Vinagre et al., 2008), which may impair the colonization by larvae.

\section{Acknowledgements}

The authors would like to express their gratitude to Daniel Crespo, Dániel Nyitrai, João Rito, Cláudia Moreira, Rita Guillot and Hans Witte for the valuable help in sampling in the Mondego estuary, Wadden Sea and in the Sørfjord, to Louis Quiniou and Rachid Amara for providing flounder samples from the French estuaries, and to Catarina Vinagre and Audrey Geffen, for helping with the otolith reading procedures. Filipe Martinho was funded by the Portuguese Foundation for Science and Technology (FCT), through a post-doc grant (SFRH/BPD/63527/2009). The manuscript was greatly improved by the comments of three anonymous reviewers and the handling editor.

\section{References}

Amara, R., Lagardère, F., Desaunay, Y., Marchand, J., 2000. Metamorphosis and estuarine colonization in the common sole, Solea solea (L.): implications for recruitment regulation. Oceanologica Acta 23, 469-484.

Amara, R., Selleslagh, J., Billon, G., Minier, C., 2009. Growth and condition of 0-group European flounder, Platichthys flesus as indicator of estuarine habitat quality. Hydrobiologia 627, 87-98.

Bailey, K.M., Nakata, H., van der Veer, H.W., 2005. The planktonic stages of flatfishes: physical and biological interactions in transport processes. In: Gibson, R.N. (Ed.) Flatfishes: Biology and Exploitation. Blackwell Science, Oxford, U.K., pp. 94-119.

Bailey, K.M., Abookire, A.A., Duffy-Anderson, J.T., 2008. Ocean transport paths for the early life history stages of offshore-spawning flatfishes: a case study in the Gulf of Alaska. Fish and Fisheries 9, 44-66.

Bergman, M.J.N., van der Veer, H.W., Stam, A., Zuidema, D., 1989. Transport mechanisms of larval plaice (Pleuronectes platessa L.) from the coastal zone into the Wadden Sea nursery area. Rapports et Procès-verbaux des Réunions/Conseil Permanent International pour l'Exploration de la Mer 191, 43-49.

Bolle, L.J., Dickey-Collas, M., van Beek, J.K.L., Erftemeijer, P.L.A., Witte, J.I.J., van der Veer, H.W., Rijnsdorp, A.D., 2009. Variability in transport of fish eggs and larvae. III. Effects of hydrodynamics and larval behaviour on recruitment in plaice. Marine Ecology Progress Series 390, 195-211.

Borsa, P., Blanquer, A., Berrebi, P., 1997. Genetic structure of the flounders Platichthys flesus and P. stellatus at different geographic scales. Marine Biology 129, 233-246.

Bos, A.R., 1999. Tidal transport of flounder larvae (Platichthys flesus) in the Elbe River, Germany. Archive of Fishery and Marine Research 47, 47-60.

Brunel, T., Boucher, J. 2006. Pattern of recruitment variability in the geographical range of the exploited northeast Atlantic fish species. Journal of Sea Research 55, 156-168.

Buckley, L.J., 1982. Effects of temperature on growth and biochemical composition of larval winter flounder Pseudopleuronectes americanus. Marine Ecology Progress Series 8 181-186.

Cabral, H.N., Vasconcelos, R.P., Vinagre, C., França, S., Fonseca, V., Maia, A., Reis-Santos, P., Lopes, M., Ruano, M., Campos, J., Freitas, V., Santos, P.T., Costa, M.J., 2007. Relative importance of estuarine flatfish nurseries along the Portuguese coast. Journal of Sea Research 57, 209-217.

Campos, J., Freitas, V., Pedrosa, C., Guillot, R., van der Veer, H.W., 2009. Latitudinal variation in growth of Crangon crangon (L.): does counter-gradient growth compensation occur? Journal of Sea Research 62, 229-237. 
Conover, D.O., Present, T.M.C., 1990. Countergradient variation in growth rate: compensation for length of the growing season among Atlantic silversides from different latitudes. Oecologia 83, 316-324.

Curry-Lindahl, K., 1985. Våra fiskar. Havsoch sötvattensfiskar i Norden och övriga Europa.P.A. Norstedt \& Söners förlag, Stockholm.

Dando, P.R., 2011. Site fidelity, homing and spawning migrations of flounder Platichthys flesus in the Tamar estuary, South West England. Marine Ecology Progress Series 430, 183-196.

Daverat, F., Morais, P., Dias, E., Babaluk, J., Martin, J., Eon, M., Fablet, R., Pécheyran, C., Antunes, C., 2012. Plasticity of European flounder life history patterns discloses alternatives to catadromy. Marine Ecology Progress Series 465, 267-280.

De Groot, S.J., 1971. On the relationships between morphology of the alimentary tract, food and feeding behaviour in flatfishes (Pisces: Pleuronectiformes). Netherlands Journal of Sea Research 5, 121-196.

Duffy-Anderson, J.T. Blood, D.M., Mier, K.L. 2011. Stage-specific vertical distribution of Alaska plaice (Pleuronectes quadrituberculatus) eggs in the eastern Bering Sea. Fisheries Bulletin 109, 162-169.

Fincham, J.I., Rijnsdorp, A.D., Engelhard, G.H., 2013. Shifts in the timing of spawning in sole linked to warming sea temperatures. Journal of Sea Research 75, 69-76.

Florin, A.-B., Höglund, J., 2008. Population structure of flounder (Platichthys flesus) in the Baltic Sea: differences among demersal and pelagic spawners. Heredity 101, 27-38.

Fonds, M., 1979. A seasonal fluctuation in growth rate of young plaice (Pleuronectes platessa) and sole (Solea solea) in the laboratory at constant temperatures and natural daylight cycle. In: Naylor, E., Hartnoll, R.G. (Eds.), Cyclic phenomena in Marine Plant and Animals. Proceedings of the 13th European Marine Biology Symposium. Pergamon Press, Oxford, UK, pp. 151-156.

Fox, C., Geffen, A., Taylor, N., Davison, P., Rossetti, H., Nash, R., 2007. Birth-date selection in early life stages of plaice Pleuronectes platessa in the eastern Irish Sea (British Isles). Marine Ecology Progress Series 345, 255-269.

Freitas, V., Bailey, K.M., van der Veer, H.W., 2008. Population regulation of epibenthic species in coastal ecosystems, with implications for latitudinal patterns. Journal of Sea Research 60, 105-116.

Geffen, A.J., van der Veer, H.W., Nash, R.D.M., 2007. The cost of metamorphosis in flatfishes. Journal of Sea Research 58, 35-45.

Grioche, A., Koubbi, P., Sautour, B., 1997. Ontogenic migration of Pleuronectes flesus larvae in the eastern English Channel. Journal of Fish Biology 51, 385-396.

Heath, M.R., 1992. Field investigations of the early life stages of marine fish. Advances in Marine Biology 28, 2-133.

Hermant, M., Lobry, J., Bonhommeau, S., Poulard, J.-C., Le Pape, O., 2009. Impact of warming on abundance and occurrence of flatfish populations in the Bay of Biscay (France). Journal of Sea Research 64, 45-53.

Hovenkamp, F., 1990. Growth differences in larval plaice Pleuronectes platessa in the southern bight of the North Sea as indicated by otolith increments and RNA/ DNA ratios. Marine Ecology Progress Series 58, 205-215.

Hovenkamp, F., Witte, J.I.J., 1991. Growth, otolith growth and RNA/DNA ratios of larva plaice Pleuronectes platessa in the North Sea 1987 to 1989. Marine Ecology Progress Series 70, 105-116.

Hutchinson, S., Hawkins, L.E., 2004. The relationship between temperature and the size and age of larvae and peri-metamorphic stages of Pleuronectus flesus. Journal of Fish Biology 65, 445-459.

Hyder, K., Nash, R.D.M., 1998. Variations in settlement pattern of Irish Sea plaice (Pleuronectes platessa L.) as determined from a simulation model. Journal of Sea Research 40, 59-71.

ICES, 2008. Report of the 2nd Workshop on Age Reading of Flounder (WKARFLO), 26-29 May 2008.ICES, Rostock, Germany (CM 2008/ACOM:38. 53 pp.).

Jager, Z., 1999. Selective tidal stream transport of flounder larvae (Platichthys flesus L.) in the Dollard (Ems estuary). Estuarine, Coastal and Shelf Science 49, 347-362.

Kerstan, M., 1991. The importance of rivers as nursery grounds for $0-$ and $1+$ group flounder (Platichthys flesus L.) in comparison to the Wadden Sea. Netherlands Journal of Sea Research 27, 353-366.

Kooijman, S.A.L.M., 1993. Dynamic Energy Budgets in Biological Systems. Theory and Applications in Ecotoxicology.Cambridge University Press, Cambridge, UK.

Koutsikopoulos, C., Lacroix, N., 1992. Distribution and abundance of sole (Solea solea L.) eggs and larvae in the Bay of Biscay between 1986 and 1989. Netherlands Journa of Sea Research 29, 81-91.

Leggett, W.C., DeBlois, E., 1994. Recruitment in marine fishes: is it regulated by starvation and predation in the egg and larval stages? Netherlands Journal of Sea Research 32, 119-134.

Leggett, W.C., Frank, K.T., 1997. A comparative analysis of recruitment variability in North Atlantic flatfishes - testing the species range hypothesis. Journal of Sea Research 37, 281-299.

Martinho, F., Leitão, R., Neto, J.M., Cabral, H.N., Lagardère, F., Pardal, M.A., 2008. Estuarine colonization, population structure and nursery functioning for 0-group sea bass (Dicentrarchus labrax), flounder (Platichthys flesus) and sole (Solea solea) in a mesotidal temperate estuary. Journal of Applied Ichthyology 24, 229-237.

Martinho, F., Dolbeth, M., Viegas, I., Teixeira, C.M., Cabral, H.N., Pardal, M.A., 2009. Environmental effects on recruitment variability in nursery species. Estuarine, Coasta and Shelf Science 83, 460-468.
Martinho, F., Dolbeth, M., Viegas, I., Baptista, J., Cabral, H.N., Pardal, M.A., 2010. Does the flatfish community of the Mondego estuary (Portugal) reflect environmental changes? Journal of Applied Ichthyology 26, 843-852.

Miller, J.M., Burke, J.S., Fitzhugh, G.R., 1991. Early life history patterns of Atlantic North American flatfish: likely (and unlikely) factors controlling recruitment. Netherlands Journal of Sea Research 27, 261-275.

Minami, T., Tanaka, M., 1992. Life history cycles in flatfish from the northwestern Pacific, with particular reference to their early life histories. Netherlands Journal of Sea Research 29, 35-48.

Molander, A.R., 1964. Underordning plattfiskar. In: Andersson, K.A. (Ed.), Fiskar och fiske i norden. Natur och kultur, Stockholm, pp. 90-113.

Neill, W.H., Miller, J.M., van der Veer, H.W., Winemiller, K.O., 1994. Ecophysiology of marine fish recruitment: a conceptual framework for understanding interannual variability. Netherlands Journal of Sea Research 32, 135-152.

Neuheimer, A.B., Thresher, R.E., Lyle, J.M., Semmens, J.M., 2011. Tolerance limit for fish growth exceeded by warming waters. Nature Climate Change 1, 110-113.

Nissling, A., Dahlman, G., 2010. Fecundity of flounder, Pleuronectes flesus, in the Baltic Sea. Reproductive strategies in two sympatric populations. Journal of Sea Research 64, $190-198$

Pauly, D., 1994. A framework for latitudinal comparisons of flatfish recruitment. Netherlands Journal of Sea Research 32, 107-118.

Pörtner, H.O., Berdal, B., Blust, R., Brix, O., Colosimo, A., De Wachter, B., Giuliani, A., Johansen, T., Fischer, T. Knust, R. Lannig, G., Naevdal, G., Nedenes, A., Nyhammer, G., Sartoris, F.J., Serendero, I., Sirabella, P., Thorkildsen, S., Zakhartsev, M., 2001. Climate induced temperature effects on growth performance, fecundity and recruitment in marine fish: developing a hypothesis for cause and effect relationships in Atlantic cod (Gadus morhua) and common eelpout (Zoarces viviparus). Continental Shelf Research 21, 1975-1997.

R Development Core Team, 2009. R: A Language and Environment for Statistical Computing.R Foundation for Statistical Computing, Vienna, Austria (www.R-project. org)

Rijnsdorp, A.D., van Stralen, M., van der Veer, H.W., 1985. Selective tidal transport of North Sea plaice Pleuronectes platessa in coastal nursery areas. Transactions of the American Fisheries Society 114, 461-470.

Sims, D.W., Wearmouth, V.J., Genner, M.J., Southward, A.J., Hawkins, S.J., 2004. Lowtemperature-driven early spawning migration of a temperate marine fish. Journal of Animal Ecology 73, 333-341

Sobral, M.P., 2008. Aspectos relativos à biologia reprodutiva da solha, Platichthys flesus (Linnaeus, 1758), da Ria de Aveiro e litoral adjacente. Relatórios Científicos e Técnicos IPIMAR. Technical Report, 44, pp. 1-31 (in Portuguese).

Sogard, S.M., Able, K.W., Hagan, S.M., 2001. Long-term assessment of settlement and growth of juvenile winter flounder (Pseudopleuronectes americanus) in New Jersey estuaries. Journal of Sea Research 45, 189-204.

Ustups, D., Müller-Karulis, B., Bergstrom, U., Makarchouk, A., Sics, I., 2013. The influence of environmental conditions on early life stages of flounder (Platichthys flesus) in the central Baltic Sea. Journal of Sea Research 75, 77-84.

van der Veer, H.W., 1986. Immigration, settlement and density-dependent mortality of a larval and early post-larval 0-group plaice (Pleuronectes platessa) population in the western Dutch Wadden Sea. Marine Ecology Progress Series 29, 223-236.

van der Veer, H.W., Leggett, W.C., 2005. Recruitment. In: Gibson, R.N. (Ed.), Flatfishes. Biology and Exploitation. Fish and Aquatic Resources Ser, 9. Blackwell Oxford, London, pp. 120-137.

van der Veer, H.W., Bergman, M.J.N., Dapper, R., Witte, J.I.J., 1991. Population dynamics of an intertidal 0-group flounder Platichthys flesus population in the western Dutch Wadden Sea. Marine Ecology Progress Series 73, 141-148.

van der Veer, H.W., Berghahn, R., Miller, J., Rijnsdorp, A.D., 2000. Recruitment in flatfish, with special emphasis on North Atlantic species: progress made by the flatfish symposia. ICES Journal of Marine Science 57, 202-215.

van der Veer, H.W., Koot, J., Aarts, G., Dekker, R., Diderich, W., Freitas, V., Witte, J.I.J., 2011. Long-term trends in juvenile flatfish indicate a dramatic reduction in nursery function of the Balgzand intertidal, Dutch Wadden Sea. Marine Ecology Progress Series 434, 143-154.

Vasconcelos, R.P., Reis-Santos, P., Fonseca, V., Ruano, M., Tanner, S., Costa, M.J., Cabral, H.N., 2009. Juvenile fish condition in estuarine nurseries along the Portuguese coast. Estuarine, Coastal and Shelf Science 82, 128-138.

Vinagre, C., Amara, R., Maia, A., Cabral, H.N., 2008. Latitudinal comparison of spawning season and growth of 0-group sole, Solea solea (L.). Estuarine, Coastal and Shelf Science 78, 521-528.

Vinagre, C., Ferreira, T., Matos, L., Costa, M.J., Cabral, H.N., 2009. Latitudinal gradients in growth and spawning of sea bass, Dicentrarchus labrax, and their relationship with temperature and photoperiod. Estuarine, Coastal and Shelf Science 81, 375-380.

Willig, M.R., Kaufman, D.M., Stevens, R.D., 2003. Latitudinal gradients of biodiversity: pattern, process, scale, and synthesis. Annual Review of Ecology, Evolution, and Systematics 34, 273-309.

Worley, S.J., Woodruff, S.D., Reynolds, R.W., Lubker, S.J., Lott, N., 2005. ICOADS release 2.1 data and products. International Journal of Climatology 25, 823-842.

Yamashita, Y., Tanaka, M., Miller, J.M., 2001. Ecophysiology of juvenile flatfish in nursery grounds. Journal of Sea Research 45, 205-218. 